\title{
Fate of soil-applied black carbon: downward migration, leaching and soil respiration
}

\author{
JULIE MAJOR*, JOHANNES LEHMANN*, MARCORONDON ${ }^{1}$ and CHRISTINE \\ GOODALE \\ *Department of Crop and Soil Sciences, Cornell University, Ithaca, NY 14853, USA, †International Development Research Centre, \\ Ottawa, ON Canada K1G 3H9, †Department of Ecology and Evolutionary Biology, Cornell University, Ithaca, NY 14853, USA
}

\begin{abstract}
Black carbon $(\mathrm{BC})$ is an important pool of the global $\mathrm{C}$ cycle, because it cycles much more slowly than others and may even be managed for $C$ sequestration. Using stable isotope techniques, we investigated the fate of BC applied to a savanna Oxisol in Colombia at rates of $0,11.6,23.2$ and 116.1 $\mathrm{BC} \mathrm{ha}^{-1}$, as well as its effect on non-BC soil organic C. During the rainy seasons of 2005 and 2006, soil respiration was measured using soda lime traps, particulate and dissolved organic C (POC and DOC) moving by saturated flow was sampled continuously at 0.15 and $0.3 \mathrm{~m}$, and soil was sampled to $2.0 \mathrm{~m}$. Black $\mathrm{C}$ was found below the application depth of $0-0.1 \mathrm{~m}$ in the $\mathbf{0 . 1 5}-\mathbf{0 . 3} \mathrm{m}$ depth interval, with migration rates of $52.4 \pm 14.5,51.8 \pm 18.5$ and $378.7 \pm 196.9 \mathrm{kgC} \mathrm{ha}^{-1} \mathrm{yr}^{-1}( \pm \mathrm{SE})$ where 11.6, 23.2 and 116.1 $\mathrm{tBC} \mathrm{ha}^{-1}$, respectively, had been applied. Over 2 years after application, $2.2 \%$ of BC applied at $23.2 \mathrm{tBC}^{-1}$ was lost by respiration, and an even smaller fraction of $1 \%$ was mobilized by percolating water. Carbon from BC moved to a greater extent as DOC than POC. The largest flux of BC from the field (20-53\% of applied BC) was not accounted for by our measurements and is assumed to have occurred by surface runoff during intense rain events. Black $C$ caused a $189 \%$ increase in aboveground biomass production measured 5 months after application (2.4-4.5 $\mathrm{t}$ additional dry biomass ha ${ }^{-1}$ where BC was applied), and this resulted in greater amounts of non-BC being respired, leached and found in soil for the duration of the experiment. These increases can be quantitatively explained by estimates of greater belowground net primary productivity with BC addition.
\end{abstract}

Keywords: biochar, black carbon, carbon leaching, carbon sequestration, dissolved organic carbon, Oxisol, particulate organic carbon, soil carbon cycling, soil respiration

Received 27 March 2009; revised version received 8 June 2009 and accepted 28 July 2009

\section{Introduction}

Black carbon (BC) is an important C pool globally. Despite relatively low global production rates of 0.05 $0.27 \mathrm{Pg} \mathrm{yr}^{-1}$ (Forbes et al., 2006) compared with terrestrial net primary productivity of about $60 \mathrm{Pg} \mathrm{yr}^{-1}$ (Denman et al., 2007), biomass-derived BC has been found to comprise about $30 \%$ of organic $\mathrm{C}$ in $76 \%$ of 57 soils from six orders worldwide (Skjemstad et al., 1996, 1999a, b; Skjemstad \& Taylor, 1999). Therefore, BC cycles at a much slower rate than the non-BC fraction of soil organic C mainly due to its high content of aromatic, graphitic, or elemental refractory C (Glaser et al., 1998).

Correspondence: Johannes Lehmann, tel. + 1607254 1236, fax + 1 607255 2644, e-mail: CL273@cornell.edu

${ }^{1}$ Formerly at the Centro Internacional de Agricultura Tropical (CIAT), A.A. 6713 Cali, Colombia
Indeed, $\mathrm{BC}$ in deep-sea sediments has been found to be 2400-13900 years older than associated non-BC (Masiello \& Druffel, 1998). Black C has also been observed to represent the oldest $C$ fraction in soils (Pessenda et al., 2001). Understanding the stability of BC in soil is crucial in order to balance the global $\mathrm{C}$ budget (Czimczik \& Masiello, 2007). Managing BC for actively increasing the long-term $\mathrm{C}$ sink of atmospheric $\mathrm{CO}_{2}$ in the form of $\mathrm{BC}$ from biochar in soil has been proposed by Lehmann et al. (2006) and also relies on accurate information about its stability.

However, very little is known about the stability of BC under field conditions. Most studies are conducted by using laboratory incubations (Baldock \& Smernik, 2002; Cheng et al., 2008b; Liang et al., 2008; Kuzyakov et al., 2009). The few published field observations using repeated soil sampling show generally rapid disappearance rates (Bird et al., 1999; Hammes et al., 2008; Nguyen 
et al., 2008) which may be explained by the fact that a full mass balance was not possible and some BC loss may have occurred by mass transport rather than mineralization.

Despite the observed long-term stability of BC, significant initial mineralization is likely to occur. Rapid oxidation over several months of incubation was reported for experimentally produced BC (Cheng et al., $2006,2008 a)$. BC generated in the laboratory is likely to contain a range of compounds exhibiting varying stability (Lehmann, 2007). During the first 10 years after $B C$ deposition following forest fires in Kenya, the O/C ratio significantly increased on BC surfaces (Nguyen et al., 2008), and 100-year-old BC particles in Kenya (Nguyen et al., 2008) and dissolved BC-derived molecules in the United States (Hockaday et al., 2007) were found to be significantly altered, bearing abundant carboxyl groups. The dynamics of BC mineralization during the first years after deposition to field soil have not been studied up to now.

Several studies have argued that BC might stimulate the rates of loss of non-BC soil C (Pietikäinen et al., 2000; Wardle et al., 2008), and proposed mechanisms for this include priming of decomposition by labile $\mathrm{C}$ (glucose) (Hamer et al., 2004), and the sorption by BC of compounds which inhibit microbial growth, such as phenols (Gundale \& DeLuca, 2007). No data have been reported that test these processes under field conditions in mineral soil.

In addition to mineralization to $\mathrm{CO}_{2}, \mathrm{BC}$ may be transported in the landscape (Rumpel et al., 2006a, b; Hockaday et al., 2007; Guggenberger et al., 2008) both laterally and vertically through soil. While BC has been identified in dissolved organic C (DOC) (Guggenberger et al., 2008) and particulate organic C (POC) (Mitra et al., 2002) of natural river water, the magnitude of leaching with percolating soil water has not been quantified. Similarly unclear is whether BC moves primarily in dissolved or particulate form. Several authors have identified surface-deposited BC in subsoils (e.g. Brodowski et al., 2007; Leifeld et al., 2007). Yet while the $B C$ was found to be associated with coarse silt and sand (Brodowski et al., 2007), actual mechanisms for its movement have not been established. Black $\mathrm{C}$, alone or associated with mineral fractions, could move through soil by facilitated transport in macropores. Particles with a median size of $2-5 \mu \mathrm{m}$ moved from topsoil through a sandy loam in the field (Laubel et al., 1999), and natural colloids of up to $200 \mu \mathrm{m}$ were mobilized through a coarse disturbed soil (Totsche et al., 2007), also in the field. Black $C$ found in soil has very similar size distributions, with most of the particles typically being smaller than $50 \mu \mathrm{m}$ (Skjemstad et al., 1996).
This work was undertaken to assess the fate of biomass-derived BC after addition to surface soil in the field over 2 years. Our hypotheses were: (i) $\mathrm{CO}_{2}$ evolution will initially increase due to rapid mineralization of the labile fraction of $\mathrm{BC}$; (ii) longer-term mineralization of BC over 2 years will be low due to its high stability; (iii) $\mathrm{BC}$ will move rapidly into the subsoil; and (iv) $\mathrm{BC}$ will mainly travel in dissolved form through a poorly aggregated clay Oxisol.

\section{Materials and methods}

\section{Site characteristics}

Experimental plots were established at Matazul farm in the Llanos Orientales nonflooded savanna region of Colombia $\left(04^{\circ} 10^{\prime} 15.2^{\prime \prime} \mathrm{N}, 07^{\circ} 36^{\prime} 12.9^{\prime \prime} \mathrm{W}\right)$. The soil in the experimental plots is an isohyperthermic kaolinitic Typic Haplustox sandy clay loam (Soil Survey Staff, 1994), which developed from alluvial sediments originating in the Andes (Rippstein et al., 2001). Long-term average annual rainfall measured approximately $200 \mathrm{~km}$ northeast of the plot is $2200 \mathrm{~mm}$, and $95 \%$ of precipitation falls between April and December. A marked dry season occurs between January and March, and average annual temperature is $26^{\circ} \mathrm{C}$. Based on stable $C$ isotope signatures, present-day native $C_{4}$ vegetation dominated the area for a very extensive period, perhaps since the Late Glaciation Period (Behling \& Hooghiemstra, 1998). Trees are found almost exclusively along waterways, except in areas where fire control has been practiced in modern times. This $\mathrm{C}_{4}$ vegetation results in $\delta^{13} \mathrm{C}$ values for soil of -10.9 to $-13.5 \%$ up to a depth of $2 \mathrm{~m}$ as measured in this experiment.

\section{Field experiment}

The BC applied to the plots was produced in a controlled manner, in order to provide sufficient amounts for a replicated experiment that included high application rates, and yielded the most uniform BC material that could be obtained under local conditions. Black $C$ material 1 was produced in December 2004 from prunings of old mango (Mangifera indica L.) trees, with a resulting $\delta^{13} \mathrm{C}$ value of $-29 \%$ (Table 1). A mound of tightly packed logs (approximately $2 \mathrm{~m}$ high, $5 \mathrm{~m}$ diameter) was formed, covered with dry grass and soil, and ignited through a tunnel at the base. The temperature in simple kilns may range between 400 and $600{ }^{\circ} \mathrm{C}$ and carbonization times typically last $48 \mathrm{~h}$ (Emrich, 1985). Black C was then ground by hand using a metallic disk pestle, to pass through a $0.9 \mathrm{~mm}$ sieve, and mixed well. Black $C$ generated under natural fires 
Table 1 Properties of BC applied to a Colombian savanna Oxisol

\begin{tabular}{lcc}
\hline & \multicolumn{2}{l}{ BC material } \\
\cline { 2 - 3 } & 1 & 2 \\
\hline $\mathrm{pH}\left(\mathrm{H}_{2} \mathrm{O}\right)$ & 10.14 & 10.07 \\
$\mathrm{pH}(\mathrm{KCl})$ & 8.92 & 8.74 \\
Total C $(\%)$ & 71.7 & 63.5 \\
$\delta^{13} \mathrm{C}(\%)$ & -28.86 & -28.20 \\
Total N $(\%)$ & 0.26 & 0.32 \\
$\mathrm{C} / \mathrm{N}$ & 280 & 197 \\
$\mathrm{H} / \mathrm{C}$ & 0.022 & 0.027 \\
$\mathrm{O} / \mathrm{C}$ & 0.22 & 0.23 \\
$\mathrm{Ash}(\%)$ & 8.8 & 12.0 \\
$\mathrm{Ca}\left(\mathrm{mg} \mathrm{g}^{-1}\right)^{*}$ & 2.93 & 6.44 \\
$\mathrm{Mg}\left(\mu \mathrm{g} \mathrm{g}^{-1}\right)^{*}$ & 291 & 185 \\
$\mathrm{P}\left(\mu \mathrm{g} \mathrm{g}^{-1}\right)^{*}$ & 259 & 116 \\
$\mathrm{~K}\left(\mathrm{mg} \mathrm{g}^{-1}\right)^{*}$ & 3.30 & 2.61 \\
$\mathrm{CEC}\left(\mathrm{mmol}_{\mathrm{c}} \mathrm{kg}^{-1}\right)$ & 235 & 248 \\
\hline
\end{tabular}

Values are averages of two analytical replicates. BC material 2 was used in the experiment to assess $\mathrm{CO}_{2}$ losses during the first year after BC application.

*Available nutrient contents.

BC, black carbon.

(Masiello, 2004) or produced using modern technology for deliberate application as biochar (Lehmann, 2007) can have varying properties. Depending on the charred biomass type and charring conditions, chemical properties including decomposability may differ significantly (Baldock \& Smernik, 2002; Antal \& Grønli, 2003). The results shown here have to be viewed in the context of the BC material used (Table 1).

At the onset of the dry season in December 2004, BC was incorporated to soil under native savanna vegetation which to our knowledge had never been tilled or cropped. The fields were selected on a flat plain with no visible inclination and the slope was estimated to have been at most $2 \%$. The site was mowed, and disked to break up the soil. A randomized complete block design was applied, with plots measuring $4 \times 5 \mathrm{~m}$, using three replications. Black $C$ application rates were $0,11.6,23.2$ and $116.1 \mathrm{tBC} \mathrm{ha}^{-1}(n=3)$. These rates correspond approximately to a $50 \%$ increase, doubling and fivefold increase in soil C in the top $0.1 \mathrm{~m}$, respectively. Skjemstad et al. (1999a) reported a maximum, conservative estimate of BC content in Australian soils of $28 \mathrm{t} \mathrm{BC} \mathrm{ha}^{-1}$ (at our soil's density and application depth), and the rate of $116.1 \mathrm{tBC} \mathrm{ha}{ }^{-1}$ brought the soil in the range of soil organic $\mathrm{C}$ (SOC) stocks found in BC-rich Amazonian Terra preta soils (147-506 $\mathrm{tC} \mathrm{ha}^{-1} \mathrm{~m}^{-1}$ ) (Glaser et al., 2003). Black $C$ was applied to each plot uniformly using rakes, and incorporated to $0.1 \mathrm{~m}$ with two disk harrow passes. The control plots were also disked.

\section{Soil sampling}

On 13-16 December 2006, i.e. two rainy seasons after application, soil was sampled in all plots, in depth increments of $0-0.15,0.15-0.3,0.3-0.6,0.6-1.2$ and $1.2-2 \mathrm{~m}$. Sampling was carried out manually to $0.6 \mathrm{~m}$ with a $\sim 50 \mathrm{~mm}$ diameter corer, and using a tractordriven hydraulic version of the same corer to $2 \mathrm{~m}$. Composite samples were taken in each plot, from five random sampling locations to $0.6 \mathrm{~m}$ and three of these locations to $2 \mathrm{~m}$, and hand mixed in buckets before a $\sim 500 \mathrm{~g}$ subsample was taken for analysis. These subsamples were air-dried, crushed and passed through an aluminum sieve with $2 \mathrm{~mm}$ circular holes.

Soil was analyzed for particle size distribution by the hydrometer technique (Bouyoucos, 1927), after dispersion with sodium hexametaphosphate. In July 2006, additional samples were taken for physical property analysis, using aluminum cores. In each plot, a small pit was dug to $0.3 \mathrm{~m}$, and subsamples were taken from two opposite sides of pits from the surface, 0.15 and $0.3 \mathrm{~m}$ depths. Two cores ( $50 \mathrm{~mm}$ diameter, $50 \mathrm{~mm}$ high) were taken at each depth and from each side of the pits. For depths of $0.6,1.2$ and $2 \mathrm{~m}$, we assumed no effect of BC application on physical properties and two soil pits located 5-10 $\mathrm{m}$ away from the experiment were used. In each of these pits, cores were taken from two profiles on the side closest to the experiment. This yielded a total of four samples for each sampling depth.

Bulk density was determined by oven drying at $105^{\circ} \mathrm{C}$ for $24 \mathrm{~h}$ for samples from all plots and depths (84 samples). Samples to $0.3 \mathrm{~m}$ depth from the control and $23.2 \mathrm{tBC} \mathrm{ha}{ }^{-1}$ treatments were used to determine saturated hydraulic conductivity with a constant head permeameter. Abnormally high saturated hydraulic conductivity data for one of the control plots, at $0.3 \mathrm{~m}$, was removed before statistical analysis due to the observation of high termite activity in that plot and depth.

\section{Carbon leaching measurement}

In May 2005, free-draining lysimeters for measuring POC and DOC in water moving by saturated flow were installed in the unamended control and the plots receiving $23.2 \mathrm{tBC} \mathrm{ha}^{-1}$. These were inserted from soil pits at depths of 0.15 and $0.3 \mathrm{~m}$, in 'galleries' dug from the face of the pits and into the experimental plots. The lysimeters consisted of $0.15 \mathrm{~m}$ diameter Pyrex ${ }^{\mathbb{R}}$ (Corning Inc., Corning, NY, USA), glass funnels filled with quartz sand after washing with dilute $\mathrm{HCl}$ and $\mathrm{NaOH}$, held by a glass wool plug. The $\mathrm{C}$ content of the sand after washing was $0.04 \%$ by weight. Two funnels were placed at each depth in each plot. Funnel pairs were 
fitted with plasticizer-free Tygon ${ }^{\circledR}$ (St-Gobain Performance Plastics, Akron, OH, USA) (Formula 2075) hose and the hoses joined with acopper ' $\mathrm{T}$ ' fitting, itself draining into one amber glass bottle (washed as described above). This yielded a total of 24 funnels and 12 collection bottles ( 1 per depth per plot). Field collection bottles were checked at least weekly, and emptied when water had been collected. After each emptying of bottles, a solution of $\mathrm{HgCl}_{2}$ was added as a biocide to achieve a final concentration of $30 \mu \mathrm{M}$ in a 1$\mathrm{L}$ sample. Water sampling was carried out between May 2005 and January 2006 (year 1), and March and December 2006 (year 2). At each collection time, the height of water in the bottles was recorded and converted into volume using a curve created with the bottles. Upon collection, water samples were stored in borosilicate glass vials with Teflon ${ }^{\mathbb{R}}$-lined caps and refrigerated at $4{ }^{\circ} \mathrm{C}$ until analyzed. Samples were not refrigerated for 3-5 days while being shipped to the United States.

Depending on sample availability, $40-60 \mathrm{~mL}$ of each water sample was vacuum filtered using glazed ceramic Buchner funnels through binder-free glass filters (What$\operatorname{man}^{\circledR}$, Whatman plc, Kent, ME, USA, GF/F; $13 \mathrm{~mm}$ diameter, $0.7 \mu \mathrm{m}$ pore size), which were then dried at $60{ }^{\circ} \mathrm{C}$ for $24-36 \mathrm{~h}$, cut up, and placed in tin cups for $\mathrm{C}$ and $\mathrm{N}$ analysis by dry combustion. Filtered water samples were freeze-dried in progressively smaller glass vials, and the solids weighed and prepared for $\mathrm{C}$ and $\mathrm{N}$ analysis by dry combustion. In the present study, we used $0.7 \mu \mathrm{m}$ to separate DOC from POC. However, we recognize that this separation is operational and that some colloids may have sizes of $<0.7 \mu \mathrm{m}$.

For the calculation of total $\mathrm{C}$ leaching, the flux in each lysimeter was multiplied by the $\mathrm{C}$ concentration in the sample. On two dates no samples were available for analysis for the control due to sample loss. For one of these dates the value was calculated as the average of the two adjacent dates, since these were very similar. In the other case, the date was dropped completely since no assumption of similarity could be made.

\section{Soil respiration measurement}

Static-chamber soda lime traps (after Edwards, 1982) were used in order to determine the amount and isotopic composition of soil-respired $\mathrm{CO}_{2}$. Plastic rings obtained from cutting 20-L buckets $(0.273 \mathrm{~m}$ diameter) were buried into the soil to a depth of $0.1 \mathrm{~m}$ and measurements started in the second year after BC application on April 6 2006. To discern the short-term response of respiration during the first year after $B C$ addition, a second set of rings was installed on 11 May 2006 on an adjacent area, and identically treated using BC material 2 which was produced similarly to material
1, except a soil trench was used instead of a mound (Table 1). In both sets of plots, two rings were inserted at random locations away from the edges inside each replicate plot of the $23.2 \mathrm{tBC} \mathrm{ha}^{-1}$ and control treatments, for a total of 24 . The soil inside the rings was kept free of vegetation. Initially, $30 \mathrm{~g}$ of four to eight mesh soda lime with indicator were exposed in each chamber, based on recommendations from Edwards (1982). After 5 weekly trials, the amount of soda lime was reduced to $10 \mathrm{~g}$, since $\mathrm{CO}_{2}$ absorption did not exceed $10 \%$ of the saturation value for this amount of soda lime (as specified by the manufacturer). The highest mass of $\mathrm{CO}_{2}$ absorbed in a single trial represented $11 \%$ of the mass of soda lime used. Before field exposure, soda lime was dried in wide-mouth $(44 \mathrm{~mm})$ glass jars for $24 \mathrm{~h}$ at $105^{\circ} \mathrm{C}$, capped tightly, cooled and then weighed on a scale with $1 \mathrm{mg}$ resolution. Uncapped jars ('traps') were placed on elevated pieces of wire mesh, on the soil inside each ring. Chamber tops were formed from the rest of the $20 \mathrm{~L}$ plastic buckets, sealed using a thick, tight rubber band covering the junction. Control traps were placed in the plots, in chambers of the same internal volume as the treatment chambers. However, they consisted of two bucket bottoms sealed together, i.e. no soil was exposed. Initially, one control trap was used in each plot (total 12 control traps), but after observing low variability among control traps, their number was reduced to six for the entire experiment. Sampling frequency was initially weekly, but was reduced to biweekly halfway into the rainy season.

The soda lime was left in the field for $24 \mathrm{~h}$, removed and dried again for $24 \mathrm{~h}$ as above. Final mass was obtained and the difference between initial and final mass multiplied by 1.69 to correct for chemical water generation during the process of $\mathrm{CO}_{2}$ absorption (Grogan, 1998). Control traps account for $\mathrm{CO}_{2}$ absorbed during drying, manipulation, from the initial atmosphere inside the chamber and any additional $\mathrm{CO}_{2}$ contributed by leaks in chamber seals. Absorbed $\mathrm{CO}_{2}$ mass for the controls were averaged, and this average value subtracted from absorbed $\mathrm{CO}_{2}$ mass in each treatment jar. The maximum standard error observed among control traps was $17 \%$ for the duration of the experiment. Trapped $\mathrm{CO}_{2}$ mass was further corrected for time of exposure, which differed from $24 \mathrm{~h}$ by a maximum of $74 \mathrm{~min}$ over the duration of measurements.

The amount of $\mathrm{CO}_{2}$ trapped depended in part on the diameter of the jars used to expose the soda lime. On four occasions it was necessary to use jars of different mouth size. To correct for this difference, a relationship was established between mouth size and $\mathrm{CO}_{2}$ trapped by exposing jars of various sizes $(30-44 \mathrm{~mm}$ mouth diameter) to ambient air for approximately $60 \mathrm{~h}$. This trial was repeated four times and conversion factors averaged. 
Exposed soda lime jars were sealed with Teflon ${ }^{\circledR}$ tape and stored in sealed drums with silica gel to absorb humidity. Samples were later composited into periods defined by peaks in amount of $\mathrm{CO}_{2}$ absorbed over time (Fig. 4). All samples for dates within individual peak absorption periods were combined, mixed, and a subsample ground for $90 \mathrm{~s}$ by hand using a mortar and pestle. For the first and last sampling dates, subsamples were combined but replicates and controls were analyzed separately, to provide more detailed data as well as information on variability. Approximately $0.2 \mathrm{~g}$ of ground composited soda lime was placed into acidwashed glass tubes, which were then sealed and evacuated. Three milliliters of phosphoric acid $(40 \%)$ were added, and the tubes were set on an orbital shaker for $1 \mathrm{~h}$. The headspace gas was then sampled using a syringe and transferred to evacuated single-use tubes.

\section{Plant biomass sampling}

Plant biomass was sampled on 19 October 2006, where all aboveground vegetation inside two $1-\mathrm{m}^{2}$ quadrats was sampled in three replicated plots of the control and 23.2 $\mathrm{tBC} \mathrm{ha}^{-1}$, on the new set of plots used for first year soda lime measurements. Vegetation was separated into grasses, forbs and legumes, and fresh and dry mass was determined after drying at $65^{\circ} \mathrm{C}$ for $72 \mathrm{~h}$.

\section{Analytical procedures}

Air-dried BC and soil were ground using a ball grinder (Oscillating Mill MM400 by Retsch, Newtown, PA, USA). Carbon and $\mathrm{N}$ contents and isotope ratios were determined by combustion on an isotope ratio mass spectrometer (IRMS; Europa Hydra 20/20 by Europa Scientific, Crewe, UK) for solid samples, and gas on a GC-C-IRMS (Europa Geo 20/20-Orchid by Europa Scientific). The $\mathrm{H}$ content of $\mathrm{BC}$ was measured by combustion on an oxygen analyzer (PDZ Europa 2020, Heckatech HT by Europa Scientific). Ash content was measured according to ASTM (2007). To measure $\mathrm{pH}, \mathrm{BC}$ was mixed with either water or $1 \mathrm{~N} \mathrm{KCl}$ in a $1: 10$ mass: volume ratio, stirred three times over $1 \mathrm{~h}$ and the $\mathrm{pH}$ was read with a gel epoxy electrode (Symphony by VWR, West Chester, PA, USA). Cation exchange capacity (CEC) of BC was determined by double extraction with $1 \mathrm{~N}$ ammonium acetate at $\mathrm{pH}$ 7, flushing with isopropyl alcohol followed by double $2 \mathrm{~N} \mathrm{KCl}$ extraction. The ammonium content of the $\mathrm{KCl}$ extract was determined colorimetrically using a Technicon ${ }^{\circledR}$ flow analyzer (Technicon Corporation) and Nessler's reagent (Naude, 1927). Available nutrients were extracted using $2.5 \mathrm{~g} \mathrm{BC}$ and $25 \mathrm{~mL}$ Mehlich III solution (Mehlich, 1984), followed by shaking for $5 \mathrm{~min}$ and filtering. Nutrients $(\mathrm{K}, \mathrm{Ca}, \mathrm{Mg}, \mathrm{P})$ were analyzed by ICP atomic emission spectrometry (IRIS Intrepid by Thermo Elemental, Franklin, MA, USA).

\section{Calculations and statistical analyses}

The amount of $\mathrm{C}$ contributed by $\mathrm{BC}$ and soil in samples was calculated as follows:

$$
\delta^{13} C_{A+B}(A+B)=\delta^{13} C_{A} A+\delta^{13} C_{B} B,
$$

where $\delta^{13} \mathrm{C}_{\mathrm{A}}$ is the $\delta^{13} \mathrm{C}$ of corresponding control soil within field replicate, $\delta^{13} \mathrm{C}_{\mathrm{B}}$ the $\delta^{13} \mathrm{C}$ of $\mathrm{BC}, \delta^{13} \mathrm{C}_{\mathrm{A}+\mathrm{B}}$ the $\delta^{13} \mathrm{C}$ of field sample, $A$ the amount of $\mathrm{C}$ derived from $\mathrm{C}_{4}$ sources (soil-C), $B$ the amount of $C$ from $B C, A+B$ is the total amount of $C$ in field sample.

When no corresponding control was available for a specific sample, the average $\delta^{13} \mathrm{C}$ of controls for that date was used. When no controls were available for a specific date, the average $\delta^{13} \mathrm{C}$ of controls at the closest date was used. It is recognized that end members may not necessarily contribute $C$ with isotopic values that are identical to the bulk $\delta^{13} \mathrm{C}$. For example, the easily mineralizable or leachable fraction of $\mathrm{BC}$ may have a different $\delta^{13} \mathrm{C}$ than the total BC. This could be due to the fact that lignin is typically depleted in ${ }^{13} \mathrm{C}$ compared with other plant compounds (Benner et al., 1987) and greater $\mathrm{BC}$ yields from lignin than from cellulose or hemicellulose (Yang et al., 2007). However, C isotope ratios have not been found to change with increasing charring temperature of $\mathrm{C}_{3}$ plants (Krull et al., 2003) suggesting that labile and stable $\mathrm{BC}$ fractions have similar $\delta^{13} \mathrm{C}$ values compared with the large differences between the C3-derived $B C$ and the $\mathrm{C}_{4}$ vegetation.

Statistical analyses were conducted using the general linear model procedure of SAS (SAS Institute Inc., (2003) SAS version 9.1 for Windows, Cary NC), and means separated using the $t$-test at $\alpha=0.05$.

\section{Results}

\section{Soil}

The highest rate of BC application $\left(116.1 \mathrm{tBC} \mathrm{ha}^{-1}\right)$ reduced soil bulk density at the surface and $0.15 \mathrm{~m}$ depths $(P<0.05)$ (Fig. 1). Also, BC application significantly increased saturated hydraulic conductivity at the surface from 2.7 to $13.4 \mathrm{~cm} \mathrm{~h}^{-1}$ in the control and $23.2 \mathrm{tBC} \mathrm{ha}^{-1}$ application rate, respectively (data not shown).

Soil C contents were greater in plots receiving greater amounts of BC (Fig. 2), although only the highest BC application rate resulted in a significant difference from the control $(P<0.05)$ at $0-0.15 \mathrm{~m}$ depth. For the $0.15-0.3 \mathrm{~m}$ depth increment, both the 23.2 and 116.1 $\mathrm{tBC} \mathrm{ha}^{-1}$ rates had significantly more total $\mathrm{C}$ than 
the control $(P<0.05, n=3)$. Black $C$ was found mostly in the surface layer which comprised the application depth with the highest application rate producing a significantly greater $\mathrm{BC}$ stock than others $(P<0.05$, $n=3)$. Small amounts of applied BC were also found in the $0.15-0.3 \mathrm{~m}$ depth increment, with the high application rate (116.1 tha $\left.{ }^{-1}\right)$ always resulting in significantly greater $(P<0.05) \mathrm{BC}$ stocks than the control (Fig. 2). When controlling for bulk density, the non-BC stock was greater in the high $\mathrm{BC}$ application rate than the control at both the $0-0.15$ and $0.15-0.3 \mathrm{~m}$ depths, after 2 years (Fig. 2). The concentration of non-BC was greater with all $\mathrm{BC}$ application rates $(P<0.05)$ at $0-0.15 \mathrm{~m}(6.48$, 8.01, 7.81 and $10.25 \mathrm{mg} \mathrm{soil} \mathrm{Cg} \mathrm{soil}^{-1}$ for $0,11.6,23.2$ and $116.1 \mathrm{tBC} \mathrm{ha}^{-1}$ applied, respectively). Only the highest rate significantly increased non- $\mathrm{BC}$ content at $0.15-0.3 \mathrm{~m}$, from 4.60 to $6.46 \mathrm{mg}$ soil $\mathrm{C}$ g soil ${ }^{-1}(P<0.05)$.

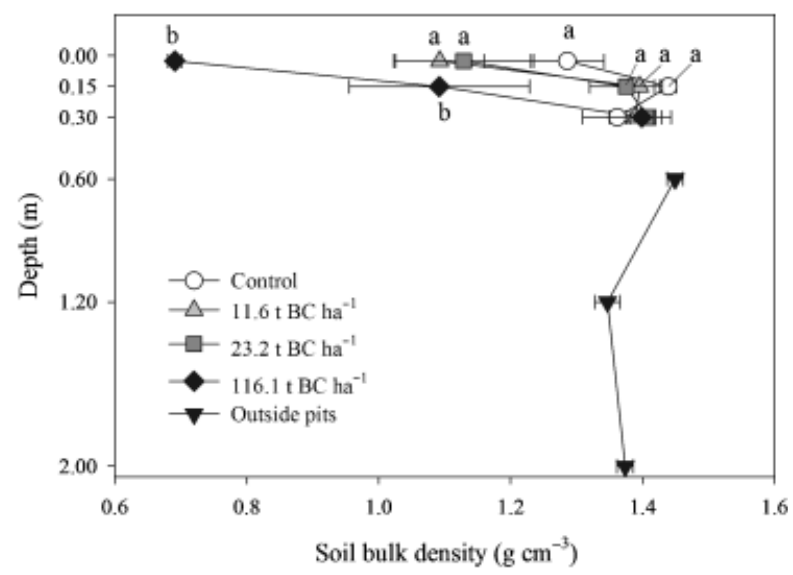

Fig. 1 Bulk density of a Colombian savanna Oxisol, 18 months after $\mathrm{BC}$ incorporation to $0.1 \mathrm{~m}$ ( $\pm \mathrm{SE}, n=6$ to $0.3 \mathrm{~m}$ depth, and $n=4$ below $0.3 \mathrm{~m})$. Significant differences $(P<0.05)$ within a

\section{Plant biomass}

Total aboveground plant biomass measured 5 months after biochar application increased by $189 \%$ when $23.2 \mathrm{tBC} \mathrm{ha}^{-1}$ was applied. Grasses, forbs and legumes on BC amended plots had 93, 292 and 1916\% greater biomass, respectively, than on plots without $\mathrm{BC}$ application $(P<0.05)$. The proportions of forbs and legumes were also greater when $\mathrm{BC}$ was applied (Table 2).

Biomass was not measured in year 2 , however, it was observed in the second-year plot that vegetation composition had greater similarity to that which predominates in the region and which covered the plots before establishment. Grasses dominated and forbs were not as prominent, with or without BC application, than when sampling was carried out at 5 months.

\section{Carbon leaching}

The concentration of POC in water was greater at both 0.15 and $0.3 \mathrm{~m}(P<0.0001$ and $<0.005$, respectively $)$ in fields with $23.2 \mathrm{tBC} \mathrm{ha}^{-1}$ than those without $\mathrm{BC}$ additions. Results were similar for the total flux of POC

Table 2 Amount and proportion of above-ground biomass of spontaneous vegetation sampled on a control and BCamended (23.2 $\mathrm{tC} \mathrm{ha}^{-1}$ ) Colombian savanna Oxisol

\begin{tabular}{lllllr}
\hline & \multicolumn{2}{l}{$\begin{array}{l}\text { Dry matter } \\
\left(\mathrm{t} \mathrm{ha}^{-1}\right)\end{array}$} & & & \multicolumn{2}{l}{\begin{tabular}{l} 
Proportion of total \\
\cline { 6 - 6 }
\end{tabular}} & $-\mathrm{BC}$ & $+\mathrm{BC}$ & & $-\mathrm{BC}$ & $+\mathrm{BC}$ \\
\cline { 2 - 3 } & 1.13 & 2.19 & & 69 & 46 \\
Grasses & 0.47 & 1.86 & & 29 & 39 \\
Forbs & 0.04 & 0.71 & & 2 & 15 \\
Legumes & 1.64 & 4.75 & & 100 & 100 \\
Total & & &
\end{tabular}

BC, black carbon. (a)

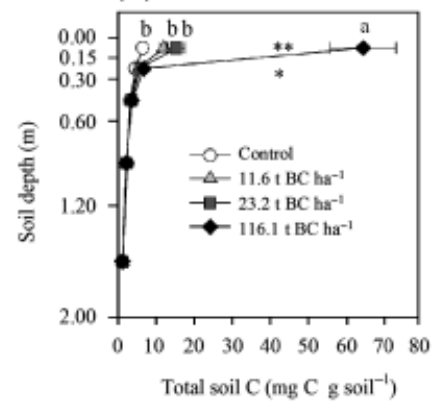

(b)

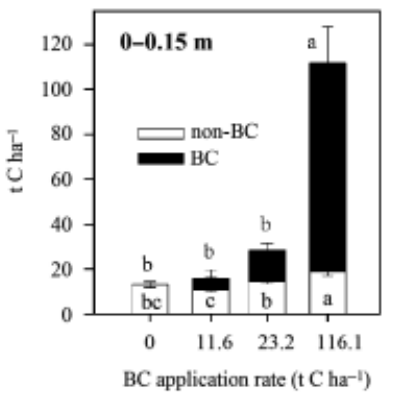

(c)

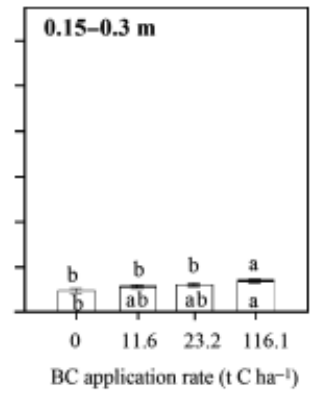

Fig. 2 Total soil C concentration (a) and C stocks from soil and BC (b and c), two rainy seasons after BC application to a Colombian savanna Oxisol under natural vegetation $( \pm S E, n=3)$. Significant differences within a single depth are represented by different lowercase letters (significant differences in total $C$ at $0.3 \mathrm{~m}$ not shown), and significant main effects are indicated by ${ }^{* *} P<0.01$ and ${ }^{*} P<0.05$. Letters showing differences in BC content in (b) and (c) are placed above bars. Points in (a) are placed at the center of the depth increment they represent. 

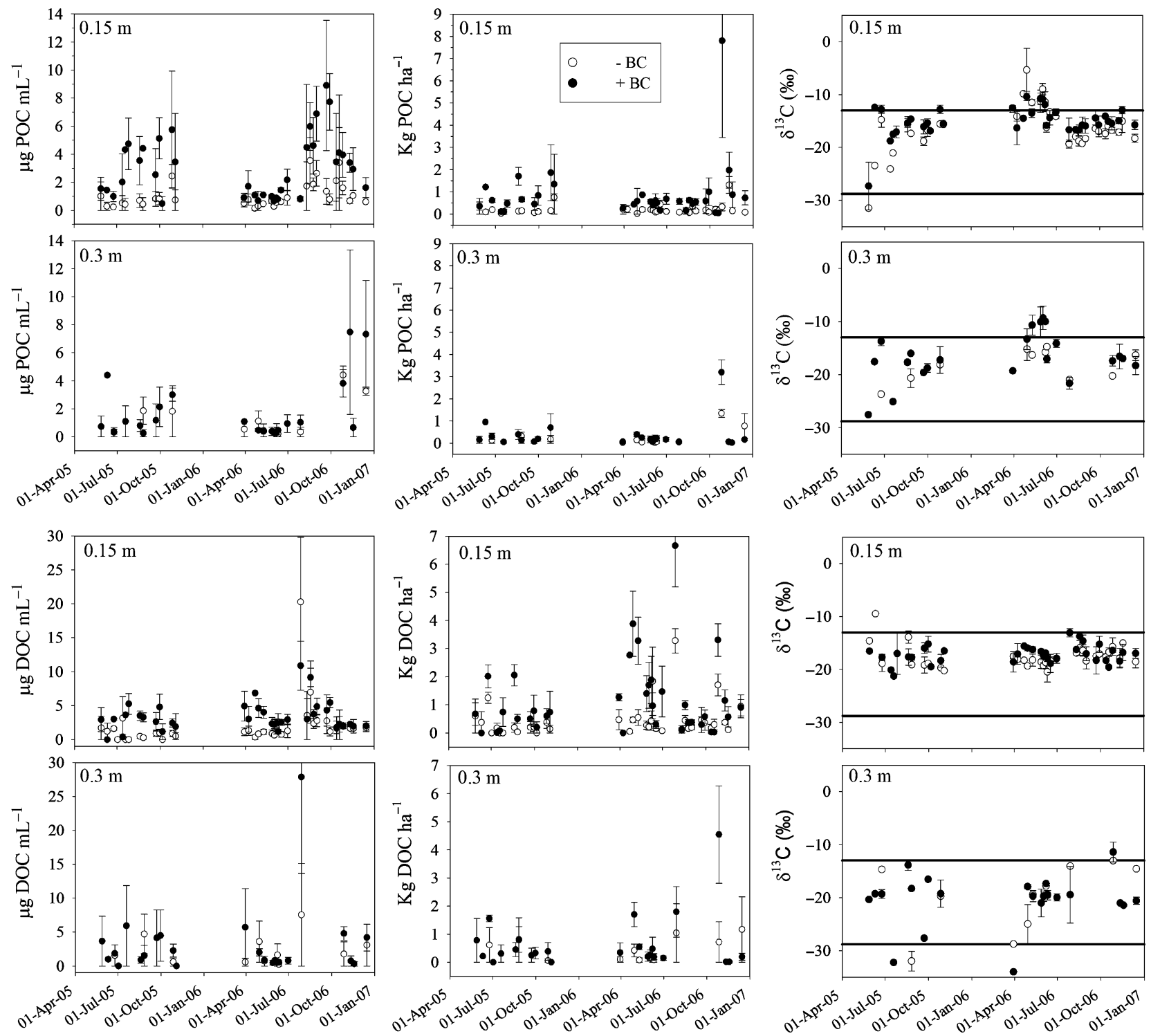

Fig. 3 Concentration (left), total amount (center) and $\delta^{13} \mathrm{C}$ values (right) of POC (top) and DOC (bottom) leached over two years in freedraining lysimeters placed at 0.15 and $0.3 \mathrm{~m}$ depth, either with $\left(+\mathrm{BC}, 23.2 \mathrm{tCha}^{-1}\right)$ or without $\mathrm{BC}$ addition $(-\mathrm{BC})$ to a Colombian savanna Oxisol under natural vegetation ( $\pm \mathrm{SE}, n=1,2$ or 3 depending on whether samples were collected for all replicates in the field, and whether samples were lost during transportation or storage). In the $\delta^{13} \mathrm{C}$ panels, the upper reference line corresponds to the $\delta^{13} \mathrm{C}$ value of the soil and the lower line to the $\delta^{13} \mathrm{C}$ value of $\mathrm{BC}$.

leached ( $P<0.005$ at both depths) (Fig. 3). Cumulatively, $317 \%$ and $267 \%$ more POC was leached at 0.15 and $0.3 \mathrm{~m}$, respectively, when $\mathrm{BC}$ was applied (only $23.2 \mathrm{tBC} \mathrm{ha}^{-1}$ was investigated for leaching in comparison with the control). At $0.15 \mathrm{~m}$, both the volumeweighted average POC concentration and total flux of POC leached were greater with $\mathrm{BC}$ addition, while at $0.3 \mathrm{~m}$ the volume-weighted concentration of POC was not significantly affected by BC additions. Greater water flux therefore explains the increase in total POC leached only at $0.3 \mathrm{~m}$ (Table 3 ). Volume-weighted $\delta^{13} \mathrm{C}$ values for POC were not significantly different between treat- ments at $0.15 \mathrm{~m}$. However, at $0.3 \mathrm{~m}, \mathrm{BC}$ additions resulted in significantly higher volume-weighted $\delta^{13} \mathrm{C}$ values. Calculated amounts of BC-derived POC leached were low (Table 3), corresponding to $<1 \%$ of applied $\mathrm{BC}$ after 2 years. Black $\mathrm{C}$ application led to greater amounts of non-BC-derived POC leached $(P<0.05)$, corresponding to increases by $308 \%$ and $254 \%$ at 0.15 and $0.3 \mathrm{~m}$, respectively over control plots.

Similar trends were observed for DOC, with cumulatively $158 \%$ and $199 \%$ more DOC and $131 \%$ and $122 \%$ more non-BC-derived DOC leached 0.15 and $0.3 \mathrm{~m}$, respectively, when $\mathrm{BC}$ was applied as compared with 
Table 3 Total amounts and volume-weighted average concentrations of $\mathrm{C}$ leached over 2 years as POC and DOC, at 0.15 and $0.3 \mathrm{~m}$ depths on a Colombian savanna Oxisol

\begin{tabular}{|c|c|c|c|c|c|c|c|c|}
\hline \multirow[b]{2}{*}{ Depth (m) } & \multirow{2}{*}{$\begin{array}{l}\begin{array}{l}\text { Volume-weighted } \\
\text { averages }\end{array} \\
\\
\text { Total C } \\
\text { conc. } \\
\left(\mu \mathrm{g} \mathrm{C} \mathrm{mL}^{-1}\right)\end{array}$} & \multicolumn{7}{|c|}{ Total amounts } \\
\hline & & $\delta^{13} \mathrm{C}(\%)$ & $\begin{array}{l}\text { C leached } \\
\left(\mathrm{kgCha}^{-1}\right)\end{array}$ & $\begin{array}{l}\text { Proportion } \\
\text { from } \\
\text { soil }(\%)\end{array}$ & $\begin{array}{l}\text { Proportion } \\
\text { from } \\
\text { BC }(\%)\end{array}$ & $\begin{array}{l}\text { Prop. of } \\
\text { applied } \\
\text { BC }(\%)\end{array}$ & $\begin{array}{l}\text { BC leaching } \\
\text { rate } \\
\left(\mathrm{kgCha}^{-1} \mathrm{yr}^{-1}\right)^{*}\end{array}$ & $\begin{array}{l}\text { BC-induced } \\
\text { increase in } \\
\text { non-BC } \\
\text { leaching } \\
\left(\mathrm{kgCha}^{-1} \mathrm{yr}^{-1}\right)^{*}\end{array}$ \\
\hline \multicolumn{9}{|l|}{0.15} \\
\hline \multicolumn{9}{|l|}{ POC } \\
\hline$-B C$ & $0.91 b$ & $-15.87 a$ & $7.3 b$ & $100 a$ & $\mathrm{Ob}$ & 0 & $\mathrm{Ob}$ & $0 \mathrm{~b}$ \\
\hline$+B C$ & $2.50 a$ & $-13.91 a$ & $30.2 \mathrm{a}$ & $98.1 b$ & $1.9 \mathrm{a}$ & 0.003 & $0.32 \mathrm{a}$ & $12.2 \mathrm{a}$ \\
\hline \multicolumn{9}{|l|}{ DOC } \\
\hline$-\mathrm{BC}$ & $2.21 b$ & $-17.57 \mathrm{a}$ & $16.8 b$ & $100 \mathrm{a}$ & $\mathrm{Ob}$ & 0 & $\mathrm{Ob}$ & $\mathrm{Ob}$ \\
\hline$+\mathrm{BC}$ & $5.73 a$ & $-16.69 a$ & $43.2 \mathrm{a}$ & $89.4 b$ & $10.6 a$ & 0.020 & $2.49 \mathrm{a}$ & $11.9 \mathrm{a}$ \\
\hline \multicolumn{9}{|l|}{0.3} \\
\hline \multicolumn{9}{|l|}{ POC } \\
\hline$-B C$ & $2.04 a$ & $-16.86 a$ & $2.2 b$ & $100 \mathrm{a}$ & $0 \mathrm{~b}$ & 0 & $0 \mathrm{~b}$ & $0 \mathrm{~b}$ \\
\hline$+\mathrm{BC}$ & $1.39 \mathrm{a}$ & $-14.95 b$ & $8.0 \mathrm{a}$ & $96.6 b$ & $3.4 \mathrm{a}$ & 0.001 & $0.15 a$ & $3.0 \mathrm{a}$ \\
\hline \multicolumn{9}{|l|}{ DOC } \\
\hline$-\mathrm{BC}$ & $5.02 \mathrm{a}$ & $-18.39 a$ & $5.2 b$ & $100 \mathrm{a}$ & $0 \mathrm{~b}$ & 0 & $0 \mathrm{~b}$ & $0 \mathrm{~b}$ \\
\hline$+\mathrm{BC}$ & $2.68 b$ & $-17.91 \mathrm{a}$ & $15.5 a$ & $74.3 \mathrm{~b}$ & $25.7 \mathrm{a}$ & 0.017 & $2.16 a$ & $3.4 \mathrm{a}$ \\
\hline
\end{tabular}

Different letters represent significant differences $(P<0.05)$ between control $(-B C)$ and $B C$-amended $(+B C)$ soil.

*Sampling was carried out over two rainy seasons and one dry season. To generate this estimate, a second dry season was assumed to last the same number of days as the season sampled.

BC, Black carbon; DOC, dissolved organic C; POC, particulate organic C.

nonamended plots. However, both volume-weighted concentrations and total amounts of DOC (in both treatments) were generally substantially greater than for POC. Also, this trend was much stronger when BC had not been applied and the relative increase of POC leaching was greater than that of DOC after BC addition. Thus, the ratio of total DOC-to-total POC was 1.43 and 2.31 at $0.15 \mathrm{~m}$ with and without $\mathrm{BC}$ addition, respectively. At $0.3 \mathrm{~m}$, these ratios were 1.93 and 2.37, respectively. The amount of $\mathrm{C}$ in DOC originating from BC was $680 \%$ greater at $0.15 \mathrm{~m}$ and $1342 \%$ greater at $0.3 \mathrm{~m}$ than that in POC, while absolute amounts of BCinduced increases in leached non-BC were similar in DOC and POC at both depths (Table 3).

\section{Soil respiration}

The amount of $\mathrm{C}$ respired followed similar trends over time in both treatments but was consistently greater $(P<0.05)$ when $\mathrm{BC}$ was added, during both the first and second year after BC application (Fig. 4; only $23.2 \mathrm{tBC} \mathrm{ha}^{-1}$ was investigated in comparison with the control). Yet overall respiration rates were greater in the first than the second year. Cumulatively, $41 \%$ and $18 \%$ more $C$ was respired when $B C$ was applied, as compared with the nonamended control, in the first and second year, respectively (Table 4).

A small percentage of respired $\mathrm{C}$ originated from applied BC $(P<0.05)$ (Table 4$)$. For the two dates where replicate samples of $\mathrm{CO}_{2}$ were analyzed, no significant difference $(P>0.05)$ in $\delta^{13} \mathrm{C}$ was found between the control and $\mathrm{BC}$-amended soil. However, BC addition resulted in a $25 \%$ increase in non-BC respired $(P<0.05)$. This increase was greater in the first year after application $(40 \%)$ than the second $(6 \%)$.

Overall, the most important fate of $\mathrm{C}$ originating from BC directly measured here was respiration (Table 5). The proportion which was mobilized by water was two (DOC) to three (POC) orders of magnitude lower. Increases in non-BC losses were also greatest for respiration, and again between two and three orders of magnitude greater than for DOC and POC, respectively.

\section{Discussion}

Vertical movement of total $C$ and $B C$ in soil

After 2 years, only a small proportion of soil-applied BC had moved below the $0.1 \mathrm{~m}$ application depth into the 0.15-0.3 m sampling depth. Leifeld et al. (2007) observed 

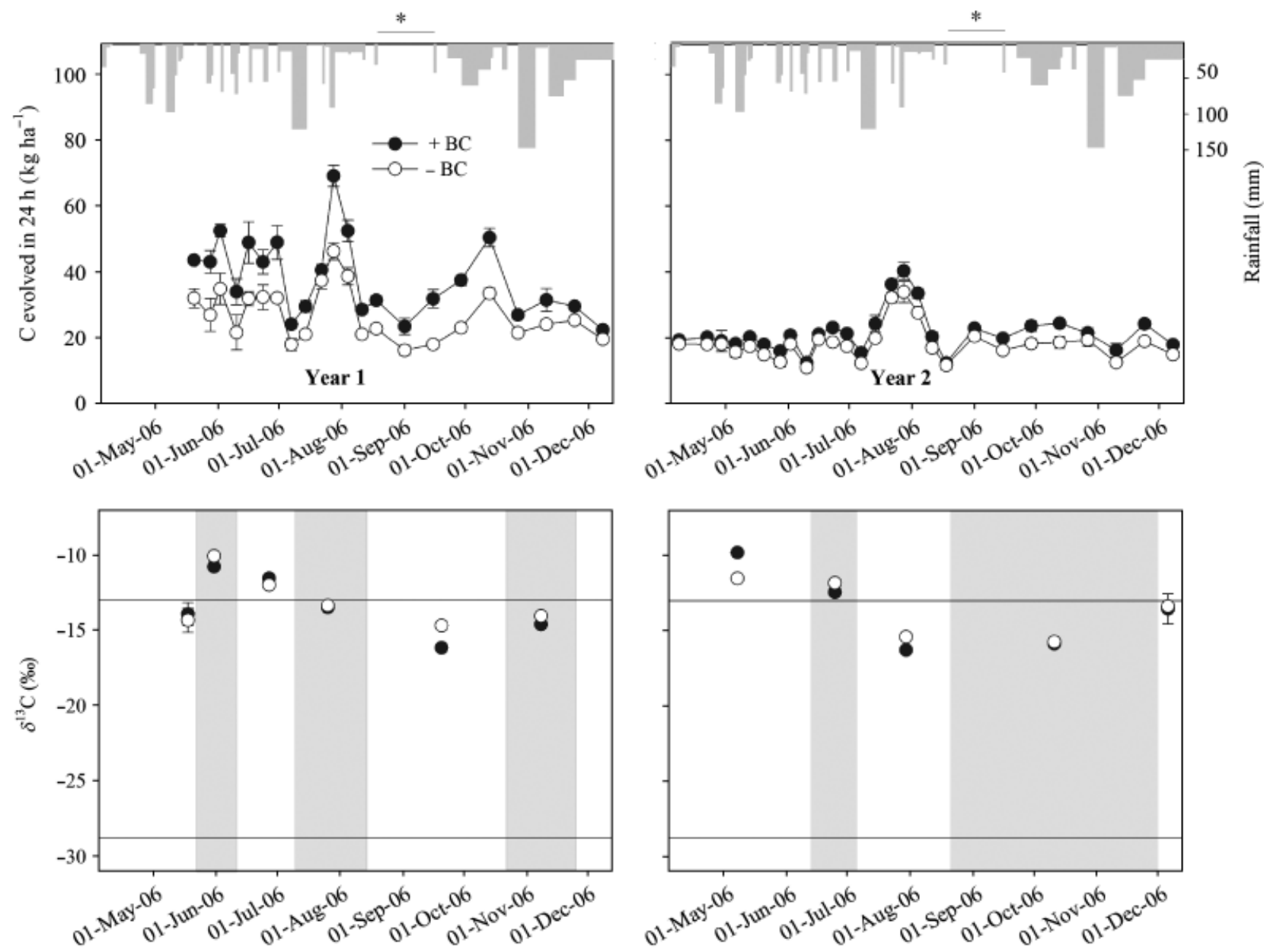

Fig. 4 Amount of $\mathrm{C}$ respired and $\delta^{13} \mathrm{C}$ from a Colombian savanna Oxisol, measured using soda lime traps ( $\pm \mathrm{SE}, n=6$ for amounts of C). Years 1 and 2 were sampled from different plots. Average rainfall collected over irregular time periods is shown with bars and given per day. For $\delta^{13} \mathrm{C}$, all samples within chosen intervals (shaded and white areas) were composited, and replicates were analyzed separately only on the first date of year 1 and the last date of year $2( \pm \mathrm{SE}, n=3)$. The upper reference line corresponds to the $\delta^{13} \mathrm{C}$ value of the soil and the lower line to the value for $\mathrm{BC} .{ }^{*}$ Missing rainfall data.

BC migration rates of $630-1160 \mathrm{~mm} \mathrm{yr}^{-1}$, where $21-69 \%$ of $\mathrm{BC}$ migrated below the incorporation depth of $0.3 \mathrm{~m}$, down to a maximum of $1.40 \mathrm{~m}$ over a maximum of 95 years in peat soils with very low bulk density. In our sandy Oxisol, BC traveled from 0.1 to $0.3 \mathrm{~m}$ with water as both POC and DOC at the first collection date after $\mathrm{BC}$ application and the onset of the rainy season. For the $23.2 \mathrm{tBC} \mathrm{ha}^{-1}$ application rate, $4.25 \mathrm{~kg} \mathrm{BC} \mathrm{ha}^{-1}(0.02 \%$ of applied amount) over 2 years moved below $0.3 \mathrm{~m}$ depth as POC and DOC (from Table 3), while $103.4 \mathrm{~kg} \mathrm{BC} \mathrm{ha}^{-1}$ ( $0.45 \%$ of applied amount) was found in soil between 0.15 and $0.3 \mathrm{~m}$ (Fig. 2). Black $\mathrm{C}$ was thus retained by the mineral subsoil.

We suspect that bioturbation could have been additionally involved in BC movement below $0.15 \mathrm{~m}$. Surface-applied lime was incorporated into an acidic Australian soil by earthworms to a depth of $0.15 \mathrm{~m}$
(Chan et al., 2004), and earthworm burrows were observed in our plots in cores from the $0.6-1.2 \mathrm{~m}$ depth increment, where the inside of the burrow was much darker in color than the surrounding soil. Termites were also observed to be active on experimental plots.

At $0-0.15 \mathrm{~m}, \mathrm{BC}$ stocks after 2 years were $53 \%, 41 \%$ and 20\% less than applied amounts of 11.6, 23.2 and $116.1 \mathrm{tBC} \mathrm{ha}^{-1}$, respectively, and leaching below $0.15 \mathrm{~m}$ accounts for a movement of $0.02 \%$ of applied BC at the $23.2 \mathrm{tha}^{-1}$ rate. Given that respiration accounted for a $2.2 \%$ loss, and that much smaller proportions were found in the soil between 0.15 and $0.3 \mathrm{~m}$ or leached below $0.3 \mathrm{~m}$, a large proportion of applied BC may have been lost by surface runoff. This represents the largest BC flux in this study. Shortly after application, biochar might have been hydrophobic (Knicker et al., 2007), which could have facilitated runoff during intense rain 
Table 4 Total C respired over 2 years from a Colombian savanna Oxisol, measured using soda lime traps during the rainy season only

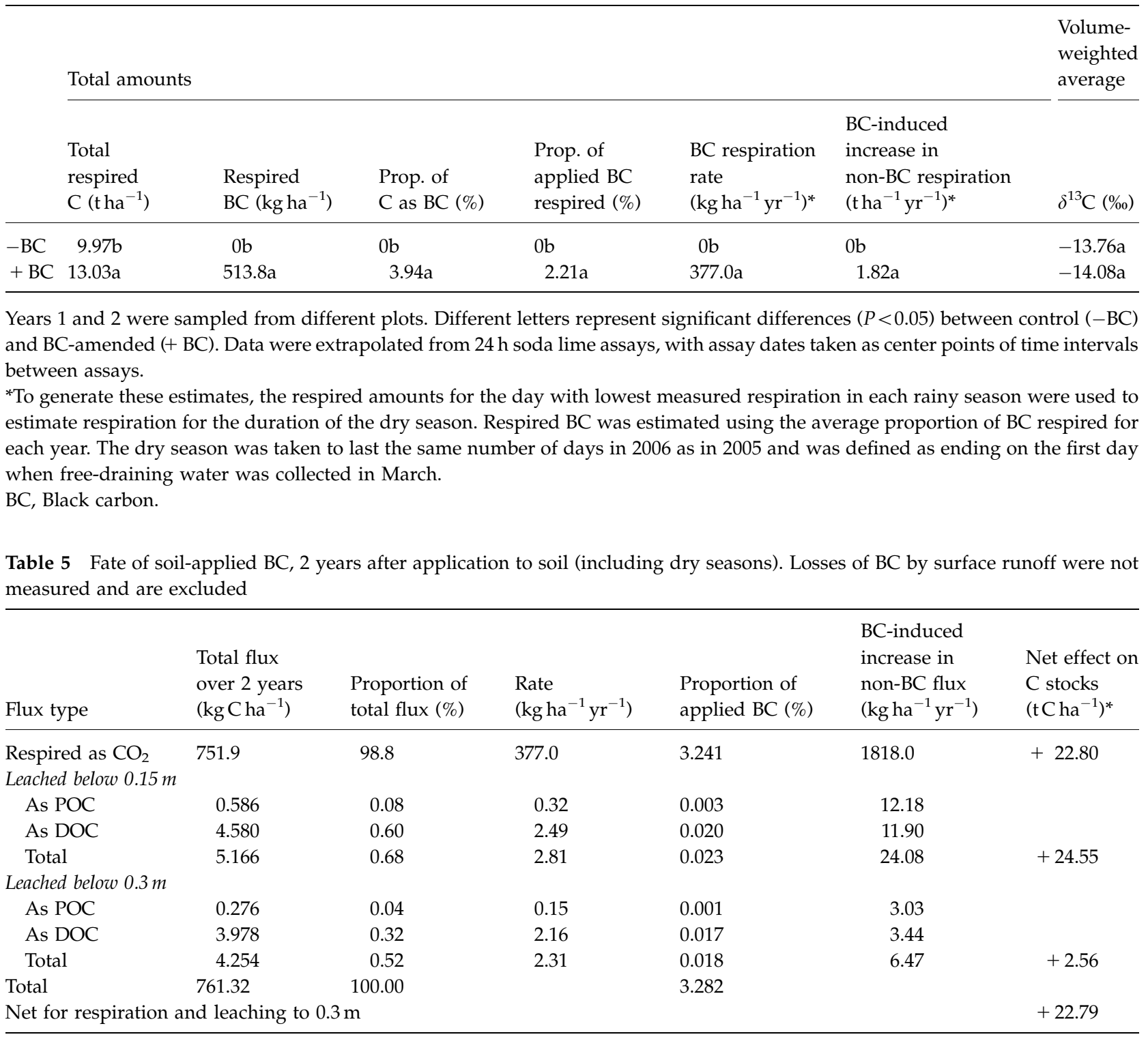

*For each line, the BC-induced 'loss' of non-BC was added to the amount of BC lost, and this was subtracted from the $\mathrm{C}$ added as $\mathrm{BC}$ $\left(23.2 \mathrm{tha}^{-1}\right.$ ) and additional non-BC as found in soil samples (Fig. 2). For respiration the depth increment used was $0-0.3 \mathrm{~m}$.

BC, Black carbon.

events. On steep slopes in Laos, surface-deposited BC was preferentially eroded in comparison with other types of soil organic matter due to its lack of association with minerals shortly after deposition, its light nature and the fact that it did not significantly degrade during transport (Rumpel et al., 2006a). Guggenberger et al. (2008) also found a larger proportion of BC from vegetation fire exported by stream water than non-BC in a tundra catchment. A total export of $1 \mathrm{~kg} \mathrm{BC} \mathrm{ha}^{-1} \mathrm{yr}^{-1}$ was observed, where 0.22 to $34.4 \mathrm{tBC} \mathrm{ha}^{-1}$ was stored in catchment soil and uniformly distributed to a depth of $1 \mathrm{~m}$. In contrast to runoff, transfer of BC between plots likely did not occur in our study, since the $\delta^{13} \mathrm{C}$ of surface soil in control plots did not change according to the direction of runoff on the field.

Lower bulk density, improved saturated hydraulic conductivity and water infiltration at the surface (Fig. 1) resulted in greater water flux at both depths when BC was added. Consequently, at $0.15 \mathrm{~m}$ the increase in total amounts of leached $\mathrm{C}$ after BC additions was proportionally greater than the increase in the volumeweighted concentration of POC as well as DOC (Table 3). At $0.3 \mathrm{~m}$, volume-weighted $\mathrm{C}$ concentrations were lower when BC was applied, but total $\mathrm{C}$ leached was 
still greater with BC addition for both POC and DOC. This implies that greater water flux was solely responsible for the increase in total $\mathrm{C}$ leached at $0.3 \mathrm{~m}$. DOC concentrations found at $0.15 \mathrm{~m}$ (mean $=2.6 \mathrm{mg} \mathrm{L}^{-1}$ ) in our study are in the range of those found at $0.1 \mathrm{~m}$ below an Oxisol in a Brazilian Amazon forest (mean = approximately $7 \mathrm{mg} \mathrm{L}^{-1}$ ) (Johnson et al., 2006).

The proportion of $\mathrm{BC}$ in DOC was much greater than $B C$ in POC (Table 3). This suggests that BC preferentially travels as colloidal particles $<0.7 \mu \mathrm{m}$, or as byproducts of $\mathrm{BC}$ decomposition and/or weathering. On the other hand, leaching of non- $\mathrm{BC}$ as a result of $\mathrm{BC}$ additions increased 3.5-4.1 times for POC, but only 2.33.1 times for DOC (Table 3). The reason may lie in the adsorptivity of $\mathrm{BC}$. Black $\mathrm{C}$ sorbs a wide range of organic compounds found in soils such as phenols (Gundale \& DeLuca, 2007), pesticides (Yu et al., 2006), glucose and DOC from birch leaf extract (Pietikäinen et al., 2000).

\section{Black $C$ effect on $C$ cycling}

The increase in respired $C$ was mostly not related to $B C$, but rather to non-BC respiration (Table 4). Still, soil respiration accounted for an overwhelmingly greater proportion of $\mathrm{BC}$ flux than movement with water (Table 5). Black $C$ may preferentially harbor microorganisms in its highly porous structure (Pietikäinen et al., 2000), and these are active as demonstrated by greater basal respiration with BC than with pumice (Pietikäinen et al., 2000) and by greater substrate-induced respiration by BC addition to forest humus (Wardle et al., 2008), in laboratory incubation studies. However, Steiner et al. (2004) found no difference in basal or substrate-induced respiration in the laboratory, when $\mathrm{BC}$ was added to either a control or synthetically fertilized Oxisol. Our results show that despite greater soil $\mathrm{C}: \mathrm{N}$ ratios with BC additions (26.1 vs. 14.8 with and without BC, respectively), soil respiration increased. Possible reasons are (i) a greater amount of biomass production and hence mineralization of plant litter; (ii) possibly a larger microbial population in soils that received $\mathrm{BC}$; or (iii) greater root respiration. The latter was partly captured here despite rings being kept free of vegetation, since they were only inserted to $0.1 \mathrm{~m}$. The increase in non-BC respired with $\mathrm{BC}$ application was greater in the first year than the second year, and this may indicate that $\mathrm{BC}^{\prime} \mathrm{s}$ stimulatory effect on soil and/or plant respiration tapers off during the first years after application.

Black $C$ application resulted in greater amounts of non-BC in soil. This follows from greater plant biomass production. A literature review by Lehmann \& Rondon (2006) found that plant biomass increased by up to
$230 \%$ with BC application in 24 experiments using 10 different crops, when compared with optimally managed controls not receiving BC. Greater plant productivity and consequently greater root and leaf turnover and microbial activity likely led to greater POC and DOC leaching with $\mathrm{BC}$ application, and explain the observed increase in non-BC cycling and non-BC soil stocks. Induced increases were greatest, in absolute terms, for respired $\mathrm{C}$ and this is in agreement with the explanation that greater non-BC fluxes with $\mathrm{BC}$ occurred through increased plant biomass, with associated increases in both heterotrophic and autotrophic respiration. Trujillo et al. (2006) estimated belowground net primary productivity to $0.5 \mathrm{~m}$ of mature savanna vegetation at $12.5 \mathrm{tha}^{-1} \mathrm{yr}^{-1}$ (5.0 $\mathrm{tCha}^{-1} \mathrm{yr}^{-1}$ with $41 \% \mathrm{C}$ in roots) on the same farm where this work was carried out, using the compartment-flow model. The calculated additional $\mathrm{C}$ input through root turnover after $\mathrm{BC}$ application would represent $29 \mathrm{tC} \mathrm{ha}^{-1}$ over 2 years, assuming that our measured increases in aboveground biomass (Table 2) translate into similar increases belowground. This amount is greater than the sum of the additional non-BC respired $\left(1.82 \mathrm{tC} \mathrm{ha}^{-1}\right)$, leached below $0.3 \mathrm{~m}$ $\left(0.007 \mathrm{tC} \mathrm{ha}^{-1}\right)$, and of additional non-BC in soil accrued to $0.3 \mathrm{~m}\left(3.98 \mathrm{tha}^{-1}\right)$ over 2 years. Thus, greater biomass production alone can explain the observed increases in non-BC fluxes, and BC-induced increased fluxes of native soil organic $C$ is unlikely the cause.

Wardle et al. (2008) observed that the addition of BC to litterbags containing boreal forest humus resulted in greater humus-C loss than expected from the loss of the components taken separately. Hamer et al. (2004) also found that $\mathrm{BC}$ enhanced the degradation of glucose in laboratory incubation studies. Our findings show the opposite, where applying $\mathrm{BC}$ to soil leads to greater non-BC content. The effect of $\mathrm{BC}$ on plant biomass and available substrates is not accounted for in data by Wardle et al. (2008), since the litter bags necessarily exclude BC-stimulated plant $C$ input. Physical export of $C$ might also have been attributed to $C$ mineralization, since mineral surfaces are expected to retain leached $\mathrm{C}$ and this would not be the case in the organic layer of the forest floor (Lehmann \& Sohi, 2008). In addition, the experiment by Hamer et al. (2004) did not include plants. Our results represent the net effect of BC on the soil and plants.

\section{Black C stability and implications for biochar soil management and $C$ sequestration}

The considerable proportion of $\mathrm{BC}$ which may have been lost by surface erosion with water could accumulate in depressions, travel mostly as sediment in waterways, potentially to the deep ocean where BC 
remains stable for thousands of years (Masiello \& Druffel, 1998).

DOC and POC leached are likely to be adsorbed in subsoils, and thus become even more stable than topsoil C. DOC concentrations in temperate and arctic forests decreased sharply as soil solution moved through mineral soil (Qualls \& Haines, 1992; Guggenberger \& Zech, 1994). Experimental evidence suggests that organic molecules such as plant-derived carbohydrates and lignins (Guggenberger \& Zech, 1994) are mainly retained abiotically by the soil matrix (Qualls \& Haines, 1992), and subsequently degraded in situ by microorganisms. Sorption of organic $\mathrm{C}$ to soil minerals is enhanced by the presence of $\mathrm{Al}$ and Fe oxides (Kaiser et al., 1996) which are abundant in Oxisols. Indeed, organic C below $0.6 \mathrm{~m}$ in a temperate grassland soil was $>2000$ years old, and had a residence time eight times greater than $C$ found at the surface (Fontaine et al., 2007). The small amounts of leached BC observed here are also expected to sorb to the mineral matrix in the subsoil.

Over 2 years, we calculated that $<3 \%$ of applied BC had been respired, of which $75 \%$ occurred during the first year. As time passes and labile $\mathrm{BC}$ fractions are mineralized, respiration of $B C$ is likely to decrease even further. Using a first-order decay model with two pools, the mean residence time (MRT) of the BC obtained from isotope recovery calculated to 600 years $\left(r^{2}=0.928\right.$; $n=12$ ). When normalized to the same mean annual temperature of $10^{\circ} \mathrm{C}$ (from $26^{\circ} \mathrm{C}$ using a $Q_{10}$ of 3.4 from Cheng et al., 2008b) the resulting MRT of 3264 years is in the same order of magnitude as that from laboratory incubation studies of similar duration using soils from charcoal storage sites (1335 years, Cheng et al., 2008b), Amazonian Dark Earths (4035 years, calculated from Liang et al., 2008), or fresh ryegrass BC (2000 years, Kuzyakov et al., 2009). Modeling to long-term equilibrium yielded slightly longer MRT of 1300 and 2600 years for BC from savanna fires in Australia at a similar mean annual temperature of $27^{\circ} \mathrm{C}$ (Lehmann et al., 2008). In addition to the degree of aging and the environmental conditions, however, also the production conditions have to be considered when comparing BC decomposition rates, for which little information is available to date.

\section{Conclusions}

Less than $3 \%$ of the applied $\mathrm{BC}$ was lost by $\mathrm{CO}_{2}$ evolution, with a calculated MRT of 600 years at $26^{\circ} \mathrm{C}$ mean annual temperature (3264 years at $10^{\circ} \mathrm{C}$ ). Since $75 \%$ of the BC losses by mineralization occurred over the course of the first year, we expect that such losses will decrease even further with time as the labile BC fraction is mineralized. These low respiration losses suggest high stability of $\mathrm{BC}$ in soils, which confirms the role that $\mathrm{BC}$ plays as a $\mathrm{C}$ sink in the global $\mathrm{C}$ cycle. When linked to sustainable and renewable feedstock production, it also affirms the validity of exploring purposeful application of BC to soils as a sink enhancement of stable SOC. We did not find evidence for an enhanced loss of existing SOC due to addition of BC, but rather greater amounts of non-BC in soil, leachate and respired $\mathrm{C}$ explainable by greater plant productivity. In addition to higher plant productivity, greater POC and DOC leaching could also be explained by a greater water flux through soil due to influences of BC on soil structure. Black $C$ additions therefore had effects on both soil and plant $\mathrm{C}$ dynamics.

The suspected physical export of BC was significantly greater than mineralization, with most of the BC likely being moved by surface erosion. This potentially large translocation of $\mathrm{BC}$ in the landscape must be recognized and losses of BC from soil cannot be interpreted solely as mineralization. We cannot provide information about whether the leached or eroded BC is mineralized to a greater or lesser extent during transport or after accumulation. Since erosion fluxes were estimated to be a significant portion of the total loss, the fate and the effects of BC moving laterally in the landscape warrant further investigation.

\section{Acknowledgements}

Our heartfelt appreciation goes out to Pedro Herrera, Diego Molina, Gonzalo Rojas and Maria del Pilar Hurtado for their dedicated help in the field. Support for J. Major was provided by a Canada Graduate Scholarship from the Natural Sciences and Engineering Research Council of Canada, and by the Saltonstall Fellowship from the Department of Crop and Soil Sciences at Cornell University. Field and laboratory work was supported by grants from Cornell's Center for the Environment, a USAID linkage grant to CIAT, the Bradfield award from Cornell's Department of Crop and Soil Sciences, Cornell's National Science Foundation (NSF) - Integrative Graduate Education and Research Traineeship (IGERT) program, as well as research travel grants from Cornell's Graduate School.

\section{References}

American Society for Testing and Materials (ASTM) (2007) Standard test method for chemical analysis of wood charcoal ASTM D1762-84 section 7.4. ASTM International, West Conshohocken PA. Available at: http:// www.astm.org/Standards/D1762.htm (Accessed 7 January 2009).

Antal MJ, Grønli M (2003) The art, science, and technology of charcoal production. Industrial \& Engineering Chemistry Research, 42, 1619-1640.

Baldock JA, Smernik RJ (2002) Chemical composition and bioavailability of thermally, altered Pinus resinosa (Red Pine) wood. Organic Geochemistry, 33, 1093-1109.

Behling H, Hooghiemstra H (1998) Late Quaternary palaeoecology and palaeoclimatology from pollen records of the savannas of the Llanos Orientales in Colombia. Palaeogeography, Palaeoclimatology, Palaeoecology, 139, 251-267. 
Benner R, Fogel ML, Sprague EK, Hodson RE (1987) Depletion of ${ }^{13} \mathrm{C}$ in lignin and its implications for carbon stable isotope studies. Nature, 329, 708-710.

Bird MI, Moyo C, Veendaal EM, Lloyd J, Frost P (1999) Stability of elemental carbon in a savanna soil. Global Biogeochemical Cycles, 13, 923-932.

Bouyoucos GJ (1927) The hydrometer as a new and rapid method for determining the colloidal content of soil. Soil Science, 23, 319-331.

Brodowski S, Amelung W, Haumaier L, Zech W (2007) Black carbon contribution to stable humus in German arable soils. Geoderma, 139, 220-228.

Chan KY, Baker GH, Conyers MK, Scott B, Munro K (2004) Complementary ability of three European earthworms (Lumbricidae) to bury lime and increase pasture production in acidic soils of south-eastern Australia. Applied Soil Ecology, 26, 257-271.

Cheng CH, Lehmann J, Engelhard M (2008a) Natural oxidation of black carbon in soils: changes in molecular form and surface charge along a climosequence. Geochimica et Cosmochimica Acta, 72, 1598-1610.

Cheng CH, Lehmann J, Thies JE, Burton S (2008b) Stability of black carbon in soils across a climatic gradient. Journal of Geophysical Research, 113, G02027.

Cheng CH, Lehmann J, Thies JE, Burton SD, Engelhard MH (2006) Oxidation of black carbon by biotic and abiotic processes. Organic Geochemistry, 37, 1477-1488.

Czimczik CI, Masiello CA (2007) Controls on black carbon storage in soils. Global Biogeochemical Cycles, 21, GB3005.

Denman KL, Brasseur G, Chidthaisong A et al. (2007) Couplings between changes in the climate system and biogeochemistry. In: Climate Change 2007: The Physical Science Basis. Contribution of Working Group I to the Fourth Assessment Report of the Intergovernmental Panel on Climate Change (eds Solomon S, Qin D, Manning M, Chen Z, Marquis M, Averyt KB, Tignor M, Miller HL), pp. 499-587. Cambridge University Press, Cambridge, UK.

Edwards NT (1982) The use of soda-lime for measuring respiration rates in terrestrial systems. Pedobiologia, 23, 321-330.

Emrich W (1985) Handbook of Charcoal Making: the Traditional and Industrial Methods. Springer, Berlin.

Fontaine S, Barot S, Barre P, Bdioui N, Mary B, Rumpel C (2007) Stability of organic carbon in deep soil layers controlled by fresh carbon supply. Nature, 450, 277-280.

Forbes MS, Raison RJ, Skjemstad JO (2006) Formation, transformation and transport of black carbon (charcoal) in terrestrial and aquatic ecosystems. Science of the Total Environment, 370, 190-206.

Glaser B, Guggenberger G, Zech W (2003) Identifying the pre-Columbian anthropogenic input on present soil properties of Amazonian dark earths (Terra Preta). In: Amazonian Dark Earths: Explorations in Space and Time (eds Glaser B, Woods WI), pp. 145-158. Springer-Verlag, Berlin.

Glaser B, Haumaier L, Guggenberger G, Zech W (1998) Black carbon in soils: the use of benzenecarboxylic acids as specific markers. Organic Geochemistry, 29, 811-819.

Grogan P (1998) $\mathrm{CO}_{2}$ flux measurement using soda lime: correction for water formed during $\mathrm{CO}_{2}$ adsorption. Ecology, 79, 1467-1468.

Guggenberger G, Rodionov A, Shibistova O et al. (2008) Storage and mobility of black carbon in permafrost soils of the forest tundra ecotone in Northern Siberia. Global Change Biology, 14, 1367-1381.

Guggenberger G, Zech W (1994) Composition and dynamics of dissolved carbohydrates and lignin-degradation products in 2 coniferous forests, Ne Bavaria, Germany. Soil Biology \& Biochemistry, 26, 19-27.

Gundale MJ, DeLuca TH (2007) Charcoal effects on soil solution chemistry and growth of Koeleria macrantha in the ponderosa pine/Douglasfir ecosystem. Biology and Fertility of Soils, 43, 303-311.

Hamer U, Marschner B, Brodowski S, Amelung W (2004) Interactive priming of black carbon and glucose mineralisation. Organic Geochemistry, 35, 823-830.
Hammes K, Torn MS, Lapenas AG, Schmidt MWI (2008) Centennial black carbon turnover observed in a Russian steppe soil. Biogeosciences, 5, 1339-1350.

Hockaday WC, Grannas AM, Kim S, Hatcher PG (2007) The transformation and mobility of charcoal in a fire-impacted watershed. Geochimica et Cosmochimica Acta, 71, 3432-3445.

Johnson M, Lehmann J, Guimaraes Couto E, Novaes Filho JP, Riha SJ (2006) DOC and DIC in flowpaths of Amazonian headwater catchments with hydrologically contrasting soils. Biogeochemistry, 81, 45-57.

Kaiser K, Guggenberger G, Zech W (1996) Sorption of DOM and DOM fractions to forest soils. Geoderma, 74, 281-303.

Knicker H, Muffler P, Hilscher A (2007) How useful is chemical oxidation with dichromate for the determination of "black carbon" in fireaffected soils? Geoderma, 142, 178-196.

Krull ES, Skjemstad JO, Graetz D, Grice K, Dunning W, Cook G, Parr JF (2003) C-13-depleted charcoal from C4 grasses and the role of occluded carbon in phytoliths. Organic Geochemistry, 34, 1337-1352.

Kuzyakov Y, Subbotina I, Chen H, Bogomolova I, Xu X (2009) Black carbon decomposition and incorporation into microbial biomass estimated by 14C labeling. Soil Biology and Biochemistry, 41, 210-219.

Laubel A, Jacobsen OH, Kronvang B, Grant R, Andersen HE (1999) Subsurface drainage loss of particles and phosphorus from field plot experiments and a tile-drained catchment. Journal of Environmental Quality, 28, 576-584.

Lehmann J (2007) Bio-energy in the black. Frontiers in Ecology and the Environment, 5, 381-387.

Lehmann J, Gaunt J, Rondon M (2006) Bio-char sequestration in terrestrial ecosystems - a review. Mitigation and Adaptation Strategies for Global Change, 11, 403-427.

Lehmann J, Rondon M (2006) Bio-Char soil management on highly weathered soils in the humid tropics. In: Biological Approaches to Sustainable Soil Systems (eds Uphoff NT, Ball AS, Fernandes E et al.), pp. 517-530. CRC/Taylor \& Francis, Boca Raton, FL.

Lehmann J, Skjemstad JO, Sohi S et al. (2008) Australian climate-carbon cycle feedback reduced by soil black carbon. Nature Geoscience, 1, 832-835.

Lehmann J, Sohi S (2008) Comment on "fire-derived charcoal causes loss of forest humus". Science, 321, 1295.

Leifeld J, Fenner S, Muller M (2007) Mobility of black carbon in drained peatland soils. Biogeosciences, 4, 425-432.

Liang B, Lehmann J, Solomon D et al. (2008) Stability of biomass-derived black carbon in soils. Geochimica et Cosmochimica Acta, 72, 6096-6078.

Masiello CA (2004) New directions in black carbon organic geochemistry. Marine Chemistry, 92, 201-213.

Masiello CA, Druffel ERM (1998) Black carbon in deep-sea sediments. Science, 280, 1911-1913.

Mehlich A (1984) Mehlich-3 soil test extractant - a modification of Mehlich-2 extractant. Communications in Soil Science and Plant Analysis, 15, 1409-1416.

Mitra S, Bianchi TS, McKee BA, Sutula M (2002) Black carbon from the Mississippi river: quantities, sources, and potential implications for the global carbon cycle. Environmental Science \& Technology, 36, 22962303.

Naude SM (1927) Information on Nessler's reagent (in German). Zeitschrift fur Physikalische Chemie-Stochiometrie und Verwandtschaftslehre, 125, 98-110.

Nguyen BT, Lehmann J, Kinyangi J, Smernik R, Riha SJ, Engelhard MH (2008) Long-term dynamics of black carbon in cultivated soil. Biogeochemistry, 89, 295-308.

Pessenda LCR, Gouveia SEM, Aravena R (2001) Radiocarbon dating of total soil organic matter and humin fraction and its comparison with 14C ages of fossil charcoal. Radiocarbon, 43, 595-601.

Pietikäinen J, Kiikkila O, Fritze H (2000) Charcoal as a habitat for microbes and its effect on the microbial community of the underlying humus. Oikos, 89, 231-242 
Qualls RG, Haines BL (1992) Biodegradability of dissolved organic-matter in forest throughfall, soil solution, and stream water. Soil Science Society of America Journal, 56, 578-586.

Rippstein G, Amezquita E, Escobar G, Grollier C (2001) Condiciones naturales de la sabana. In: Agroecologia y Biodiversidad de las Sabanas en los Llanos Orientales de Colombia (eds Rippstein G, Escobar G, Motta F), pp. 1-21. Centro Internacional de Agricultura Tropical (CIAT), Cali, Colombia.

Rumpel C, Alexis M, Chabbi A, Chaplot V, Rasse DP, Valentin C, Mariotti A (2006b) Black carbon contribution to soil organic matter composition in tropical sloping land under slash and bum agriculture. Geoderma, 130, 35-46.

Rumpel C, Chaplot V, Planchon O, Bernadou J, Valentin C, Mariotti A (2006a) Preferential erosion of black carbon on steep slopes with slash and burn agriculture. Catena, 65, 30-40.

Skjemstad JO, Clarke P, Taylor JA, Oades JM, McClure SG (1996) The chemistry and nature of protected carbon in soil. Australian Journal of Soil Research, 34, 251-271.

Skjemstad JO, Taylor JA (1999) Does the Walkley-Black method determine soil charcoal? Communications in Soil Science and Plant Analysis, 30, 2299-2310.

Skjemstad JO, Taylor JA, Janik LJ, Marvanek SP (1999b) Soil organic carbon dynamics under long-term sugarcane monoculture. Australian Journal of Soil Research, 37, 151-164.
Skjemstad JO, Taylor JA, Smernik RJ (1999a) Estimation of charcoal (char) in soils. Communications in Soil Science and Plant Analysis, 30, 2283-2298.

Soil Survey Staff (1994) Key to Soil Taxonomy. Pocahontas Press, Blacksburg, VA.

Steiner C, Teixeira WG, Lehmann J, Zech W (2004) Microbial response to charcoal amendments of highly weathered soils and Amazonian Dark Earths in central Amazonia - Preliminary results. In: Amazonian Dark Earths: Explorations in Space and Time (eds Glaser B, Woods WI), pp. 195-213. Springer-Verlag, Berlin.

Totsche KU, Jann S, Kögel-Knabner I (2007) Single event-driven export of polycyclic aromatic hydrocarbons and suspended matter from coal tarcontaminated soil. Vadose Zone Journal, 6, 233-243.

Trujillo W, Fisher MJ, Lal R (2006) Root dynamics of native savanna and introduced pastures in the Eastern Plains of Colombia. Soil and Tillage Research, 87, 28-38.

Wardle DA, Nilsson MC, Zackrisson O (2008) Fire-derived charcoal causes loss of forest humus. Science, 320, 629-629.

Yang H, Yan R, Chen H, Lee DH, Zheng C (2007) Characteristics of hemicellulose, cellulose and lignin pyrolysis. Fuel, 86, 1781-1788.

Yu XY, Ying GG, Kookana RS (2006) Sorption and desorption behaviors of diuron in soils amended with charcoal. Journal of Agricultural and Food Chemistry, 54, 8545-8550. 